\title{
Consumer Protection in E-Commerce: A Legal and Compliance Framework in the Digital Market
}

\author{
Dilshad Shaik ${ }^{1, *}$, Ms.V. Poojasree ${ }^{1}$ \\ ${ }^{1}$ School of Law, Sathyabama Institute of Science and Technology (Deemed to be University) Chennai, India \\ * Corresponding author. Email: dshaik786@gmail.com
}

\begin{abstract}
The consumer and merchant protection in business to consumers or business to business under E-Commerce has numerous serious threats viz., privacy, infringement of Intellectual Property Rights, Online Piracy, unsolicited commercial electronic advertisements and spamming, free speech and censorship and other fraudulent activities etc. Although the existence of several advantages of E-Commerce like easy access to virtual global market, reduction in distribution costs, time saving, building a healthier relationship with consumers etc, yet the legal and security risk is still a major threat in the digitalized market. Therefore, for proper functioning of E-Commerce, Consumer and merchant security is of prime importance. There are laws governing the purchasing and selling of products within ECommerce zone. But when it comes to virtual world, such as second life then and there are no laws which a merchant has to abide by. In one way this can be seen as a positive aspect but on the other hand people do have moral, social and ethical responsibilities to the users. Hence an attempt has been made out in this paper to widely discuss about the legal environment and compliance with regard to E-Commerce in the digitalized global market. Also, this paper further describes the long - arm statues and jurisdiction aspect relating to the disputes and issues in E-Commerce.
\end{abstract}

Keywords: E-Commerce, Consumer protection, digitalized market, security.

\section{INTRODUCTION}

E-Commerce is a process which makes people to buy and sell goods, transfer funds and avail services online using internet, where sellers and consumers are connected globally. This rapid commercial movement in the global digital market, though appears to be praiseworthy, has also got a deceptive phase where the consumer protection is an ultimate goal for the CyberConsumer laws. The Cyber-Consumer behaviour is a conceptual analysis of the commercial transaction among the online consumers and the online vendors. The ability of shopping from any place and any time has surprisingly increased the growth of E-Commerce, while on the other hand this feature has also paved a

\section{RESEARCH QUESTIONS}

a. Whether the deceptive phase of E-Commerce causes much impact with regard to legal and ethical issues? way for the online vendors to proceed with misleading advertisements exposing themselves to all deceptive cyber behaviour. Several Cyber-Consumer theories lean towards the emphasis on the nature and the level of understanding of the consumers about the description of product they purchase online and the content of the advertisement. These online misleading advertisements practiced by the online vendors actually claims to be false and often goes beyond the moral and ethical boundaries of commercialism. Therefore, the researcher has attempted to find out the veracity of the issues involved in E-Commerce and the redressal options accessible to the online consumers in a global perspective.

b. Whether the legal framework of International laws utilizes a sound and comprehensive framework to encompass in restraining unfair trade practices in E-Commerce? 
c. Whether the online consumers are redressed which has easy accessibility?

d. How far the online consumers are aware of the jurisdictional aspect to resolve disputes arising in E-Commerce

\section{RESEARCH OBJECTIVES}

a. To examine the veracity of legal and ethical issues involved in E-Commerce

b. To examine the legal framework of International Laws relating to unfair trade practices in $\mathrm{E}$ Commerce

c. To examine the redressable options available to online consumers in a global perspective

d. To examine the jurisdictional aspect to resolve disputes arising in E-Commerce

\section{REVIEW OF LITERATURE}

The researcher has reviewed several important and authoritative books on this subject. The various Important books together with articles and analysis published in journals and websites have been carefully studied and analysed. A detailed list of books reviewed is brought out the bibliography. The primary sources and related book on this topic reviewed are:

a. The complete E-Commerce book by Janice Reynolds

b. E-Business and E-Commerce management by Dave Chaffey

c. Law on Information Technology by Dr.Ishita Chatterjee

d. E-Commerce by Kenneth C.Laudon \& Carol Gureicier Traver

e. Legal issues in Electronic commerce by T.Rammappa

f. E-Commerce laws - law and practice (2019 Edition) by Ammu Charles The secondary sources are as follows:
a. https://sg.inflibnet.ac.in
b. https://heinonline.org
c. www.scconline.com
d. www.manupatrafast.com

\section{RESEARCH METHODOLOGY}

As this research involves a socio-legal and a conceptual study, the methodology involved is Doctrinal research. This method includes a careful analysis of various issues involved with E-Commerce. Also, the researcher has made an attempt to analyze the legal and compliance framework with regard to consumer protection in E-Commerce in a global perspective and a careful study has been made out to find the jurisdictional aspect for the disputes arising under E-Commerce. The researcher has majorly relied upon various primary and secondary sources to find out the objectives of this research.

\section{PHRENIC ANALYSIS ON MISLEADING ADVERTISEMENTS}

Way back to the evolution of the advertisement which involves a step by step development, is now facing a drastic change in adherence with the needs, beliefs and values of the society. It is highly impossible to trace out the exact point at which deceptive advertisement began, since its development the representative of the social change. It was Cohen who for the first time opened up about the false and misleading advertisement. Cohen did not regulate any of the cognitive variables which mediate the process of spotting the effects of misleading advertisement [1].

The 'Normative belief' method introduced by Garner rightly pointed out that the understanding and belief that a consumer creates for a product paves way to deceptive advertisement. [2] An advertisement is message which should comprise the exact description of a product given by the manufacturer. The ethical need of such message should be contented with utmost true information. But in reality, the advertisements are false and misleading, thereby the consumer is forced to get only deceptive descriptions about the product. As the online advertisements are not been effectively monitored as there is no stringent laws in governing the online misleading advertisements, fraudulent and deceptive acts to mislead the consumers is rapidly increasing and have become a worldwide issue for the consumers who lack knowledge on online shopping. [3] Deceptive vendors have their own lures to attract consumers that include bait and-switch schemes and blatant strategies. Mostly the online buyers are unaware of the forms of misleading advertisements and lack knowledge in that particular area. This global issue has done considerable harm, causing psychological and financial loss for the consumers. There are instances where online fraud is one of the main causes of identity theft known as phishing schemes which is a very serious crime.

\section{ISSUES IN E-COMMERCE}

Some of the recurrent ethical and legal issues faced by the online consumers when indulged in purchasing products online are as follows: [4]
a. Privacy
b. Identity and Data theft and online scams
c. Online piracy 
d. Unsolicited and misleading electronic ads and spamming

e. Fraudulent behaviour of the merchants

f. Phishing for personal financial information

g. Shopping cart abandonment

h. Insignificant customer loyalty

i. Inert behaviour of the vendor in getting back the damaged goods

j. The demand of challenging prices during shipment

k. Competing against retailers and manufacturing

1. Poor internet quality including speed and reliability

m. Deceptive description with regard to goods and services

n. Drip pricing practices as the full amount of the product is unknown till the final process of the transaction

o. Improper response to monetary refund for disgruntled products

p. Electronic identification and authentication tools

q. Concerns about Dispute Resolution mechanisms

r. Lack of basic digital skills and financial literacy

s. Competent jurisdiction and applicability of law with regard to cross-border E-Commerce transaction

As the online consumers disregard about the optin-clause and opt-out-clause, the integrity or the security of the customer data is under a major threat. Although online auction websites attempt to take several steps to verify buyer and seller identities, these safeguards are not fool proof. A fake website for a fictional business can be created easily in a very short span and often not much contact information is provided; for example, the only contact information available could be just a free or web-based email address. [5] Online deception or fraud has been in prevalence and practiced successfully due to lack of real-world accountability for online transaction.

In certain cases, major personal information, such as bank details, may be derived through insignificant level of hacking from unsecured websites. Once the hacker has enough information to impersonate someone's online persona, all sorts of online fraud can be executed. Another big issue in E-Commerce is the shopping cart abandonment. Even an expertized online vendor is able to resist this issue. [6] When an abled or a potential customer initiates the process to purchase a product online, ends up without completing the process of ordering the product is said to be abandoned for the shopper and thereby turns to be a huge loss.

\section{CROSS BORDER E-COMMERCE TRANSACTIONS}

The online buyers and sellers from across the world is easily linked through this cross-border ECommerce and therefore the online cross-border consumers face the following challenges: [7]

a. Dealing with unaccustomed brands in an unknown language

b. Deficiency of certainty in receiving a product as described or ordered

c. Hidden costs, including those related to customs duties and currency conversion, as well as shipping or delivery

d. Traditionalism of products to local standards

e. Lack of clarity on protections afforded by a seller's jurisdiction, redress available in the event of a dispute and enforcement of awards due to consumer

\section{CONSUMER PROTECTION IN E- COMMERCE}

It is worthwhile at this juncture to recall the distinction drawn between cyber-consumer redress and cyber consumer protection. Redress is a method provided by any law models considered here by which a cyber-consumer who is an aggrieved party to a CCT would seek a remedy from a merchant for nondelivery, wrong delivery of goods or fraudulent behaviour. Redress is the major concern, rather than the wider but related issue of cyber-consumer protection.

Cyber-consumer protection is a broader concept which covers issues of regulation of the bargaining phase and regulation of contract terms as well as access to justice issues. Therefore, redress is an option for the consumers to dissolve their issues and protection is a pre-action step implemented which has a thin line with redress. [8] eg. If there is greater protection through uniform and implied terms, then arguably there will be fewer disputes and these will be less costly because there will be no need for advices over private international law rules on the existing law. [9]

Therefore, the effectiveness in enacting relevant legislations and effectiveness in enforceability of redressable options for deceived online consumers. 


\section{LEGAL FRAMEWORK ON CONSUMER PROTECTION LAWS IN A GLOBAL PERSPECTIVE}

Several Countries have their own legal framework for E-Commerce and some passes regulatory bills, but varies among each other For e.g. El Salvador, Mexico and Peru rely on general civil law to regulate smooth functioning of E-Commerce. While countries like Chile, Colombia, France, the Russian Federation and the United States have an exclusive provision under Consumer Protection laws for E-Commerce. [10]

The Organization for Economic Corporation and Development (OECD) recommendation establishes the core characteristics for effective functioning of ECommerce and protection of online consumers. It also includes two new provisions in the area of privacy and security risks, payment protection and goods safety. The revised OECD recommendation of the Council concerning guidelines governing the protection of privacy and cross border flows of personal data contain basic principles, including on collection limitation, data quality, purpose specification, security safeguards, individual participation, accountability, implementation and interoperability. [11]

The efficiency of E-Commerce plays a major role in the sustainability of economic growth, enhancing the public welfare and fostering social cohesion. It is a key factor in the present scenario in the multilateral trading system. The rapid and giant growth of ECommerce will help the developing nations to meet the vital economic development such as poverty reduction, education etc. To achieve this quality in this digitized era growing benefit from the fast developing power of E-Commerce, the WTO members is expected to build a policy environment on a global scale, to improve the economic zone in an International perspective.[12]

The following conditions are paid attention by the WTO members in order to achieve the goals mentioned supra:

\section{Trade liberalization of E-Commerce related sectors:}

The liberalization of E-Commerce enabling sectors paves a bigger way in creation of a real global environment that enhances the convenience and interests of consumers. The promotion of International coordination of the industries is highly essential for the enhancement of the trade liberalization

\section{Principles for domestic regulations:}

The nature and characteristics are determined by the principles based on GATT, GATS, TRIPS and OECD. The factors like transparency in publishing all the measures, non-discriminatory treatment, avoidance of unnecessary trade restrictions, practice of globally harmonized rules of regulations and standards and recognition of equivalence of foreign regulatory measures are the considered as the general principles for the smooth functions of the domestic commercial activities.

\section{Creating a pro-competitive environment in $E$ - Commerce related market:}

An arena where local and global business agencies can access a world-wide market, should be accomplished with fair chances for entrepreneurs in both developed and developing countries to succeed in the E-Commerce. Material Competition laws and cyber consumer protection is the ultimate goal which is ensured by indirect cyber consumer protection where the market is assumed by competition law and more precisely by unfair competition dispositions and other rules aiming to achieve a liberalized and genuine competition market. The free accessibility of essential facilities, consideration for patent related issues, exclusive practices in the cyberspace and global framework for cooperation etc., are the major factors which can facilitate a pro-competitive environment in E-Commerce related market. [13]

\section{Cooperation with relevant International organizations:}

The International forums like WIPO, UNCITRAL, ISO, Hague Conference on Private International laws, OECD etc., are constantly monitoring upon the formation of International rules which focuses on IPR issues, Contract laws, authentication of digital signatures and other E-Commerce related issues. The WTO also pays more attention and attempts greatly to address various E-Commerce issues. The WTO makes its efforts to harmonize the relevant existing rules for International organization and also ensures that it reflects when domestic laws and regulations are reflected.

\section{Capacity building of developing countries:}

The developed countries are expected to pursue contributions by WTO to achieve global e-quality recognizing the diverse conditions and needs of developing economies. The developed members should undertake technical cooperation with an intention to achieve wider use of E-Commerce in developing members and share the benefits of global E-Commerce with developing members.

\section{Promotion of private sector initiatives:}

Every private sector should ensure its selfregulation to promote a deceptive free policy to deal with global business. Self-regulation shall be strengthened through public policy support. 
Governments should pursue this initiative with close dialogue with private sector-led forum such as GBDs (Global Business Dialogue on E-Commerce), GIIC (Global Information Infrastructure Commission) and other consumer groups. The members should consider a scheme that effectively reflects the views of industries and consumers in developing economies.

\section{A CONCEPTUAL FRAMEWORK ON JURISDICTIONAL ASPECT TO RESOLVE DISPUTES ARISING IN E- COMMERCE}

E-Commerce and Cyber Consumer protection has a unique hardship regarding the International jurisdictional aspect to resolve disputes arising in ECommerce. Determining the jurisdictions, the law is made by using common rules. In the European system, the Rome convention of 1980 on the applicable law in contractual matters and the Brussels convention, that is now the 44/2001 European rules on International jurisdictions, do apply. These texts contain provisions on conflicts of laws which have been drafted to protect consumers frequently allowing consumers to choose the jurisdiction of their residence. It is the role of the courts to apply those texts to specific questions resulting from electronic commerce. [14] The national reports show that the main difficulties concern the localization of the incriminated acts and the question of knowing whether those acts concern a particular market. The difficulties in determining those situations are not limited to national frontiers and the absence of unification could inspire some pessimism regarding the usefulness of classic tools in Cyber Consumer protection. The development of unfair commercial practices on the internet implies specific reactions from states. Then, it must be focused on specific electronic commerce rules that national legal systems have brought about.

To be clearer with jurisdictions over the disputes in E-Commerce, the member states should rely upon the International treaties or reciprocal enforcement agreements. These agreements often look at the contacts that the foreign entity has within the sovereign's interest in the matter of authentication.

\section{CONCLUSIONS}

In an electronic age there is a need to protect consumer's interest and the areas of central importance for the effective protection of online consumers are an informed consumer and easy accessibility to appropriate redressable laws for electronic transaction are self-sufficient to look after her/his own interest. Appropriate information on the products is very important for e-consumers as that can help them to access the benefits and risks of entering in toa particular transaction. If the consumer is already aware of such information, then there will not be unnecessary disappointment, hence subsequent disputes will be avoided. Also, as the consumers are disregarded with the terms and conditions which are legally binding and most consumers are poorly equipped to understood the significance of the terms of the contracts they enter in to.

Merchants have a deceptive behaviour in revealing information to consumers about their cancellation, return policies, including the time after entering in to a binding obligation after which an available cancellation, return or refund may be made. If there is no cancellation, return or refund right, should be stated prior completion of the transaction. [15]

The legal enactments should ensure consumers with fair and affordable means to settle disputes and obtain redress. In lieu of these facts its highly essential to have necessary legislation to protect the online consumers. According to the improvisation in this digitalized era it also essential for the member States to revise the E-Commerce legislations to accommodate the emerging issues. The key factors to improve the cyber-consumer are effective legislations and its effective enforceability, which will protect the consumers from any harm against abusive practices in E-Commerce.

\section{SUGGESTIONS}

The key factors to build the consumer confidence and fair-trade practices in E-Commerce are as follows:

a. Establishment of best network connection with high speed and reliability

b. Establishment of proper legislations and institutional framework regulating E-Commerce and to ensure enforceability also easy accessibility to dispute resolution

c. To ensure easy accessibility of dispute resolution mechanisms

d. To ensure high reliability and to reveal complete true description about the business, goods and services online

e. To ensure the reliability and security of online money transactions regardless of the mode of payment

f. To ensure the safe delivery of goods to the consumers and also to provide hassle-free after sale services

g. To ensure regional and International cooperation to fight unfair commercial practices and to overcome legal limitations impeding consumer protection authorities from taking action in the event of crossborder breaches of consumer protection law. 


\section{REFERENCES}

[1] Law on Information Technology by Dr.Ishita Chatterjee at Page No.323

[2] Awais Muhammad and Samin Tanzila (2012), "Advanced SWOT Analysis of E-Commerce", IJCSI International Journal of Computer science Issues, Vol 9, Issue 2,No 2,pp. 569-574

[3] Based on responses to the UNCTAD questionnaire on consumer protection in e-commerce, circulated to consumer protection agencies around the world

[4] Blasio,G.,D. (2008), "Urban-Rural Differences in Internet Usage, e-Commerce, and e-Banking: Evidence from Italy", Growth and Change, , pp. 341-367

[5] Chanana Nisha and Goele Sangeeta, "Future of ecommerce in India", International Journal of Computing \& Business Research, ISSN (Online): 2229-6166

[6] Contribution from Consumers International

[7] Chou,D.,C. and Chou,A.,Y. (2000), "The ECommerce Revolution, A Guide to the Internet Revolution in Banking" information systems management, pp.51-57

[8] Strauss, J., Ansary,A., E., and Frost,R.(2007), E marketing, Prentice Hall of India private limited, New Delhi

\section{[9] TD/B/C.I/CLP/23}

[10] http://www.oecd.org/internet/ieconomy/privacyguidelines.htm

[11] D'silva,B., D'Silva,S., and Bhuptani,R.,S.,K.(2010), "Behavioral Aspect of Teenagers Towards Internet Banking: An empirical study", Indian journal of marketing, 40.10, pp.44-53

[12] Singh,O.,P., and Lalwani,R.(2007), "Internet Banking-A Comparative Study on Public and Private Sector Banks in India", Indian journal of public enterprise, 22.42, pp.51-60 Snellman and

[13] Vihtkari (2003) "Customer complaining behaviour in technology-based service encounters", International Journal of Service Industry Management, Vol. 14 Iss: 2, pp.217 - 231

[14] Rust,R.,T., and Chung,T.,S. (2006) "Marketing Models of Service and Relationships" Marketing science, 25.6 , pp. 560-580

[15] Press note No.3 (2020 Series), Department for Promotion of Industry and Internal Trade, Ministry of Commerce \& Industry, Government of India 